\title{
THE IMPACT OF ACID-BASE DISORDERS IN PATIENTS WITH CHRONIC PANCREATITIS COMORBID WITH TYPE 2 DIABETES ON LONG-TERM QUALITY OF LIFE AND POSSIBLE IMPROVEMENT WITH SMALL VOLUME INFUSION THERAPY
}

The impact of acid-base disorders in patients with chronic pancreatitis comorbid with type 2 diabetes on long-term quality of life and possible improvement with small volume infusion therapy

\section{O. S. Zemlyak}

I. Horbachevsky Ternopil National Medical University

e-mail: zemliak@tdmu.edu.ua

Summary. The article presents the results of the study of metabolic endogenous intoxication indexes (MEI) reflecting intoxication by organic compounds influencing the change of physiological $\mathrm{pH}$ balance and their correlation with the presence and severity of chronic pain syndrome and quality of life criteria. The dynamics of these indexes and improvement of QOL on the background of the suggested scheme of small volume infusion detoxification therapy (SWIDT) by hyperosmolar balanced crystalloid (HSC) containing components with reserve alkalinity in the section of 30-day period were researched.

The aim of the study - to evaluate the therapeutic effect of SWIT on the severity of $\mathrm{pH}$ abnormalities as well as the effect of SWIT on the severity of chronic pain syndrome and related aspects of quality of life in patients with $C P$ in comorbidity with T2DM.

Materials and Methods. 115 patients divided into 5 groups were examined: Group 1 - 20 patients without complaints on the gastrointestinal tract, Group 2 - 30 patients with CP, Group 3-20 CP patients with concomitant T2DM received protocol treatment (PT), Group 4 and 5 $C P$ patients with concomitant T2DM, including 21 patients received $P T$ with a course of SWIT for 3 days, and 24 patients - SWIT course for 5 days. The concentration of lactate and pyruvate in blood plasma was determined, the lactate/pyruvate ratio was calculated, the concentration of bicarbonates in blood plasma was determined, pain was determined by the QLQ-C30 and PAN28 questionnaires, pain syndrome severity was determined by the visual analogue scale (VAS). Statistical processing of the obtained data was performed using Microsoft Excel 2016 and Statistica 13.0.

Results. A positive therapeutic effect on the dynamics of the level of $\mathrm{MEI}$ markers and COPD disorders in patients with CP with concomitant T2DM has been proved, which
Вплив порушень кислотно-основного співвідношення у пацієнтів із хронічним панкреатитом у коморбідності з цукровим діабетом на якість життя у віддаленій перспективі та можливості їх покращення за допомогою коригувальної програми малооб'ємної інфузійної терапії

\section{О. С. Земляк}

Тернопільський національний медичний університет імені І. Я. Горбачевського мОЗ України

Резюме. У статmі наведено результати вивчення показників метаболічної ендогенної інтоксикації (MEI), що відображають інтоксикацію органічними сполуками, які впливають на зміну фрізіологічного балансу рH та їх кореляцію з наявністю та вираженням хронічного больового синдрому і критеріїв якості життя, пов'язаних з цим показником. Досліджено динаміку цих показників та поліпшення якості життя (ЯЖ) на тлі запропонованої схеми малооб'ємної інфрузійної детоксикаційної терапії (MOIT) гіперосмолярним збалансованим кристалоїдом (ГЗК), який містить компоненти з резервною лужністю в розрізі 30-денного періоду.

Мета дослідження - оцінити терапевтичний вплив МOIT на ступінь вираження порушень $\mathrm{pH}$, а також вплив MOІT на вираження хронічного больового синдрому та аспектів якості життя у пацієнтів із ХП у коморбідності з ЦД 2 типу, пов'язаних із ним.

Матеріали і методи. Обстежено 115 пацієнтів, яких сорормували у 5 груп: перша - 20 пацієнтів без скарг з боку шлунково-кишкового тракту (ШКТ), друга - 30 хворих на хронічний панкреатит (ХП), третя група - 20 хворих на ХП із супутнім ЦД 2 типу, які отримували 3Т, четверта та і п'ята групи - хворі на ХП із супутнім ЦД 2 типу, з них 21 хворий отримував ЗТ із включенням курсу МОІТ протягом 3 днів, а 24 хворих - курс МОІт тривалістю 5 діб. Визначали концентрацію лактату і пірувату в плазмі крові, обчислювали співвідношення лактат/піруват, визначали концентрацію бікарбонатів у плазмі крові, визначали біль за опитувальниками QLQ-C30 та PAN28, вираження больового синдрому за візуально-аналоговою шкалою (ВАШ). Статистичну обробку отриманих даних проводили за допомогою Microsoft Excel 2016 ma Statistica 13.0.

Результати. Доведено позитивний терапевтичний вплив на динаміку рівня маркерів MEI та порушень КОС у хворих на ХП із супутнім ЦД 2, що свідчить про пози-
ISSN 2706-6282(print) ISSN 2706-6290(online)
Вісник медичних і біологічних досліджень Bulletin of Medical and Biological Research
$4(10), 2021$ 
indicates the positive effect of the SWIT scheme in the program of complex treatment. A clear dependence of the rate of normalization of these parameters on the duration of the SWIT course was revealed.

Conclusions. 1 Statistically significant increase of objective markers of COS impairment due to MEI (lactate, lactate/pyruvate ratio) in CP patients with concomitant T2DM in comparison with the same in isolated $C P$ was revealed $(p<0.05)$. Strong correlations between markers of $\mathrm{mEI}$ and $\mathrm{pH}$ disturbance towards metabolic acidosis mediated by lactate/pyruvate ratio and bicarbonate content were found. A higher level of efficiency of SWIT-5 application in complex therapy in comparison with MOIT-3 program has been established. It is proved that normalization of the specified indexes directly correlates with duration of the MOIT course.

Key words: chronic pancreatitis; type 2 diabetes mellitus; endogenous metabolic intoxication; small volume infusion detoxification therapy; disorders of acid-base balance; lactate; pyruvate; bicarbonate deficiency; metabolic acidosis; pain; quality of life.

\section{INTRODUCTION}

The causes of persistent metabolic acidosis in CP are: chronic inflammation of pancreatic tissue with the development of edema and impaired microcirculation and perfusion and, as a consequence, hypoxia [1]; oxidative stress of $\mathrm{CP}$ tissue with the predominance of acidic metabolites production; intestinal microflora activity with dysbacteriosis, reduced capacity of blood buffer systems [2].

An important pathogenetic factor of $\mathrm{pH}$ abnormality in patients with $\mathrm{CP}$ is concomitant diabetes mellitus [3]. Patients with both types of diabetes have high level of lactate in plasma on an empty stomach [4]. Diabetic patients with obesity have higher lactate levels compared with obese individuals without diabetes. The mechanisms underlying diabetes-associated hyperlactatemia include significant changes in intracellular glucose metabolism in insulin-sensitive tissues (decreased glycogen synthesis, impaired glucose oxidation metabolism and increased nonoxidative glycolysis rate) [5]. Thus, patients with insulin resistance/diabetes have increased glycolysis activity, which leads to the formation of NAD, pyruvate, and a decrease in NAD+ levels. There is a conversion of pyruvate to lactate by LDH by generating NAD+ from NAD in a redox reaction exacerbated by insulin resistance, as hyperinsulinemia causes increased glycolysis [6]. тивний ефрект схеми включення МОІТ у програму комплексного лікування. Виявлено чітку залежність швидкості нормалізації зазначених показників від тривалості курсу MOIT. У результаті задіяної терапії рівень лактату в плазмі крові зменшився в групі протокольного лікування на 9,52 \%, в групі МOІT 3 (протокольне лікування +курс малооб'ємної інфуузійної терапії № 3) - на 19,21 \%, і в групі MOIT 5 - на 33,14 \%, співвідношення лактат/ піруват нормалізувалося в групах порівняння на 1,63; 15,89 та 21,51 \% відповідно. Рівень больових відчуттів у групі протокольного лікування знизився на 13,73 \%, в групі MOIT 3 - на 25,48 \%, та в групі MOIT 5 - на 45,38 \%.

Висновки. Виявлено статистично достовірне підвищення об'єктивних маркерів мЕI (MCM) у хворих на ХП із супутнім ЦД 2 порівняно з таким при ізольованому ХП $(p<0,05)$. Встановлено сильні кореляційні зв'язки між МСМ та порушенням рН в сторону метаболічного ацидозу, що опосередковано відображаються співвідношенням лактат/піруват та зниженим вмістом бікарбонатів. Встановлено вищий рівень ефективності застосування у комплексній терапії MOIT-5 порівняно 3 програмою MOIT-3. Доведено, що нормалізація зазначених показників прямо корелює з тривалістю курсу MOIT.

Ключові слова: хронічний панкреатит; цукровий діабет 2 типу; ендогенна метаболічна інтоксикація; порушення кислотно-основного співвідношення; лактат; піруват; дефіцит бікарбонатів; метаболічний ацидоз; біль; якість життя.

The main buffer system of the body is the bicarbonate-haemoglobin buffer (CO2-/HCO3-), which occupies more than $70 \%$ of the total buffer capacity of the body [7]. For metabolic regulation of $\mathrm{pH}$ [8], the pancreas attracts circulating systemic bicarbonate reserves in blood. In the development of metabolic acidosis there is redistribution of bicarbonate buffer, which is reflected in the decrease of bicarbonate levels in blood [9].

Subclinical disorders of acid-base balance, according to the latest scientific data, have the following consequences for the patient [10]: directly affect the development of chronic pain syndrome, which is difficult to stop [11], worsen the effectiveness of the therapy involved, lead to chronicity of pathological processes [12], affect quality of life in the long-term period, provoke more frequent development of CP complications in comorbidity with T2DM [13].

The aim of the study - to evaluate the therapeutic effect of SWIT on the severity of chronic pain syndrome and related aspects of life quality patients with $\mathrm{CP}$ in comorbidity with T2DM.

\section{MATERIALS AND METHODS}

115 patients with $C P$ in comorbidity with $\mathrm{DM}-2$, who were admitted for treatment to the day hospital of Ternopil City Municipal Hospital No. 2 during 2017-2019, 
were examined. The control group (group 1) consisted of 20 practically healthy individuals without any complaints from the gastrointestinal tract, comparable in age, sex and social status. CP patients were divided into 5 groups: Group $1-30$ patients with CP without DM-2; Group 2 - 20 CP patients with concomitant T2DM who received conventional therapy (CT) according to the current recommendations of the Ministry of Health of Ukraine [14], Group 3-21 CP patients with concomitant T2DM, Group 4-21 CP patients with concomitant T2DM received CT with a course of small volume infusion therapy (SWIT) with hyperosmolar balanced crystalloid \#3 for 3 days; Group 5 - 24 CP patients with concomitant T2DM received ST with a course of SWIT \#5 for 5 days [15]. The mean age of CP patients was $(46.31 \pm 1.71)$ years, and that of CP patients with DM-2 was $(52.86 \pm 0.83)$ years. The mean duration of disease in group $2-(7.03 \pm 0.64)$ years, in group $3-(10.96 \pm 0.39)$ years, in group $4-$ $(10.23 \pm 0.27)$, and in group $5-(9.96 \pm 0.47)$ years. The concentration of lactate and pyruvate in blood plasma serum was determined. Lactate/pyruvate ratio was determined. Plasma bicarbonate levels were determined. Parameters related to quality of life and pain syndrome severity were assessed using Questionnaire-Core 30 (QLQ-C30), PAN28 and VAS. These parameters were re-evaluated within 30 days after admission. Statistical processing of the obtained data was performed using Microsoft Excel from Microsoft Office 365 and Statistica 13.0.

\section{RESULTS AND DISCUSSION}

Defined statistically significant expression of pain syndrome, lactate and bicarbonate concentrations in blood plasma and lactate/pyruvate ratio.

We assessed the degree of severity of individual parameters of acid-base ratio in dynamics (at admission and one month after treatment), as well as the severity of CPS and related aspects of QOL of patients with CP comorbid with T2DM (Table 1).

After treatment, the main studied parameters in the groups changed as follows: lactate level decreased in the protocol treatment group by $9.52 \%$, in SWIT 3 group (CP+T2DM Protocol treatment+ SWIT 3) by $19.21 \%$, in SWIT 5 group (CP+T2DM Protocol treatment+ SWIT 5) by $33.14 \%$, the lactate/pyruvate ratio normalized in the groups by $1.63 \%, 15.89 \%$ and $21.51 \%$ appropriately. Pain level on VAS decreased in the protocol treatment group by $13.73 \%$, in the SWIT 3 group by $25.48 \%$ and in the SWIT 5 group by $45.38 \%$. (Diagram 1).

On the RA Pain scale, the scores of the treatment protocol group normalized by $31.92 \%$, the SWIT3 group by $38.9 \%$, and the SWIT5 group by $40.74 \%$ (Diagram 2).

On the basis of the correlation-regression analysis between the parameters of lactate, pyruvate and bicarbonate deficiency and severity of chronic pain syndrome we found a significant level of close correlation relations, indicating that the levels of lactate, pyruvate and plasma bicarbonates are absolutely informative reliable in the long-term period (Table 2).

On the background of small-volume infusion therapy we observe statistically significant decrease in markers of endogenous intoxication [9], and as a consequence - more rapid normalization of the main indices, indicating a direct impact of the duration of small-volume infusion therapy on the normalization of disorders.

This indicates the effectiveness of the proposed scheme of therapy, allowing more effectively and in a shorter time to stop the undesirable phenomena of endogenous intoxication, and as evidenced by the data obtained by correlation analysis, affect the course of the pathological process itself, reducing its severity and duration of manifestation.

Table 1. Levels of key mediated markers of acid-base imbalance and quality of life related to pain syndrome at admission and by 30-day period from the start of hospitalization

\begin{tabular}{|c|c|c|c|c|c|c|c|}
\hline \multicolumn{2}{|c|}{ Parameter } & Lactate & Pyruvate & $\begin{array}{c}\text { The ratio of } \\
\text { L/P }\end{array}$ & $\begin{array}{c}\text { Bicarbonate } \\
\text { of blood } \\
\text { plasma }\end{array}$ & VAS & RA Pain \\
\hline \multicolumn{2}{|l|}{ Control group } & $0.84 \pm 0.02$ & $0.08 \pm 0.02$ & $10.50 \pm 0.72$ & $21.30 \pm 0.91$ & $0.90 \pm 0.08$ & $12.30 \pm 0.15$ \\
\hline \multirow[t]{2}{*}{$\mathrm{CP}$} & on admission & $2.10 \pm 0.07$ & $0.18 \pm 0.03$ & $11.67 \pm 0.94$ & $17.10 \pm 1.52$ & $3.18 \pm 0.64$ & $31.52 \pm 5.08$ \\
\hline & 1 month & $1.90 \pm 0.84$ & $0.17 \pm 0.02$ & $11.18 \pm 0.86$ & $19.20 \pm 1.57$ & $2.73 \pm 0.74$ & $21.87 \pm 3.21$ \\
\hline \multirow{2}{*}{$\begin{array}{l}\mathrm{CP}+\mathrm{T} 2 \mathrm{DM} \\
\text { Protocol treat- } \\
\text { ment }\end{array}$} & on admission & $3.14 \pm 0.77$ & $0.26 \pm 0.02$ & $12.08 \pm 1.06$ & $15.30 \pm 1.02$ & $3.70 \pm 0.55$ & $38.41 \pm 3.16$ \\
\hline & 1 month & $2.97 \pm 1.01$ & $0.25 \pm 0.08$ & $11.88 \pm 1.15$ & $17.40 \pm 1.83$ & $2.51 \pm 0.58$ & $26.15 \pm 4.05$ \\
\hline \multirow{2}{*}{$\begin{array}{l}\mathrm{CP}+\mathrm{T} 2 \mathrm{DM} \\
\text { (Protocol treat- } \\
\text { ment+ SWIT 3) }\end{array}$} & on admission & $3.28 \pm 0.84$ & $0.26 \pm 0.045$ & $12.62 \pm 1.79$ & $16.10 \pm 1.06$ & $3.75 \pm$ & $37.94 \pm 2.94$ \\
\hline & 1 month & $2.65 \pm 0.53$ & $0.25 \pm 0.07$ & $10.60 \pm 1.05$ & $19.60 \pm 2.94$ & $2.12 \pm 0.82$ & $23.18 \pm 3.04$ \\
\hline \multirow{2}{*}{$\begin{array}{l}\mathrm{CP}+\mathrm{T} 2 \mathrm{DM} \\
\text { (Protocol treat- } \\
\text { ment+ SWIT 5) }\end{array}$} & on admission & $3.41 \pm 0.34$ & $0.27 \pm 0.50$ & $12.63 \pm 2.08$ & $15.70 \pm 4.71$ & $3.68 \pm 0.94$ & $38.02 \pm 5.19$ \\
\hline & 1 month & $2.28 \pm 0.64$ & $0.23 \pm 0.52$ & $9.91 \pm 0.11$ & $19.70 \pm 2.86$ & $2.01 \pm 0.88$ & $22.53 \pm 3.78$ \\
\hline
\end{tabular}

ISSN 2706-6282(print) ISSN 2706-6290(online)
Вісник медичних і біологічних досліджень Bulletin of Medical and Biological Research
$4(10), 2021$ 


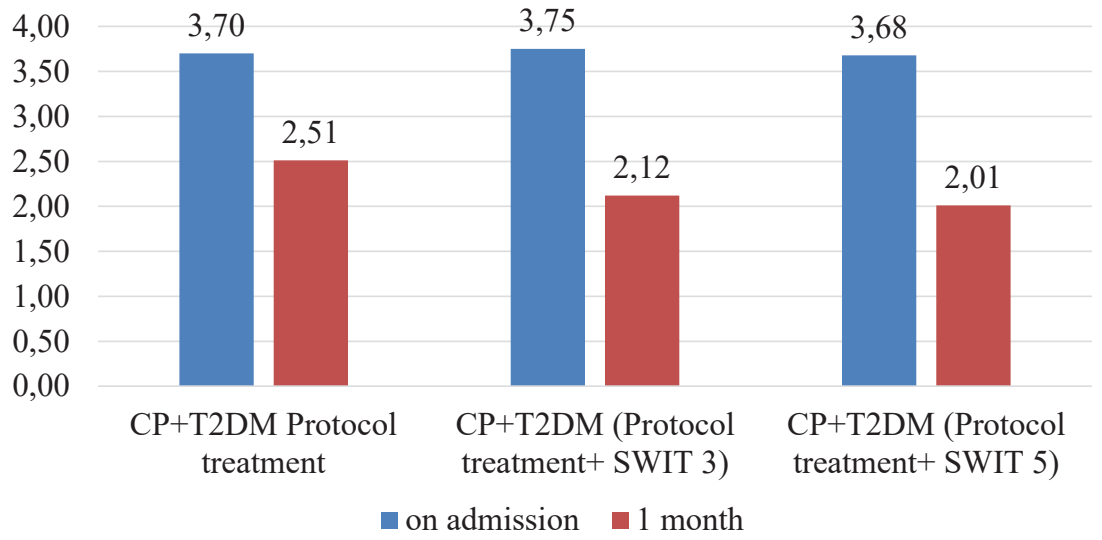

Diagram 1. Dynamics of pain syndrome on the VAS scale, $p<0.05$.

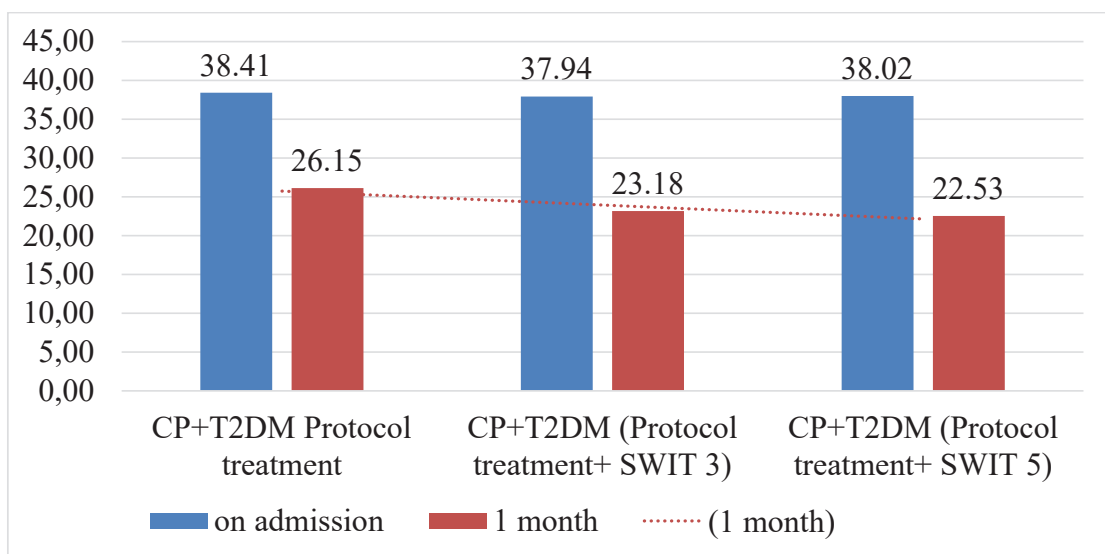

Diagram 2. Dynamics of quality of life on parameter RA Pain, $p<0.05$.

Table 2. The level of closeness of correlation relations of pain syndrome severity and lactate concentration, lactate/pyruvate ratio and blood plasma bicarbonate content

\begin{tabular}{l|c|c|c}
\hline \multicolumn{1}{c|}{ Betting on a corelative ring } & Concentration of lactate & lactate/pyruvate ratio & bicarbonate level \\
\hline Pain (VAS) & 0.705 & 0.513 & -0.570 \\
& $p<0.001$ & $p<0.001$ & $p<0.001$ \\
\hline RA Pain & 0.651 & 0.480 & -0.594 \\
& $p<0.001$ & $p<0.001$ & $p<0.001$ \\
\hline
\end{tabular}

\section{CONCLUSIONS}

1. Statistically significant increase of objective markers of $A B R$ impairment due to mEl (lactate, lactate/pyruvate ratio) in $\mathrm{CP}$ patients with concomitant T2DM in comparison with the same in isolated CP was revealed $(p<0.05)$

2. Strong correlations between markers of $\mathrm{mEl}$ and $\mathrm{pH}$ disturbance towards metabolic acidosis mediated by lactate/pyruvate ratio and bicarbonate content were found.

3. It was found that under the influence of SWIT, the dynamics of normalization of the studied indices demonstrated better normalization trends compared to the protocol therapy group. Lactate level decreased in the protocol treatment group by $9.52 \%$, in SWIT 3 group (CP+T2DM Protocol treatment+SWIT 3) by $19.21 \%$, in SWIT 3 group (CP+T2DM Protocol treatment+SWIT 5) by $33.14 \%$, the lactate/pyruvate ratio normalized in the groups by $1.63 \%, 15.89 \%$ and 21.51 $\%$ appropriately. Pain level decreased in the protocol treatment group by $13.73 \%$, in the SWIT 3 group by $25.48 \%$, in the SWIT 5 group by $45.38 \%$

4. A higher level of efficiency of SWIT-5 application in complex therapy in comparison with SWIT-3 program has been found.

5. It is proved that normalization of the specified indexes directly correlates with duration of the SWIT course. 


\section{LIST OF LITERATURE}

1. Melamed P. Chronic metabolic acidosis destroys pancreas. Biotherapy Clinic of San Francisco, USA / P. Melamed, F. Melamed // JOP. - 2014. - Vol. 15 (6). P. 552-560. DOI: 10.6092/1590-8577/2854.

2. Biomarkers of chronic pancreatitis: a systematic literature review / Z. Cruz-Monserrate, K. Gumpper, V. Pita [et al.] // Pancreatology. - 2021. - Vol. 21 (2). - P. 323-333. DOI: 10.1016/j.pan.2021.01.006.

3. Lomakina E. Y. Chronic pancreatitis and diabetes mellitus: a review of the literature / E. Y. Lomakina, O. V. Taratina, E. A. Belousova // Almanac Clin. Med. 2019. - Vol. 47 (6). - P. 525-534. DOI: 10.18786/20720505-2019-47-075.

4. Kellerund J. Diagnosis of pancreatic exocrine insufficiency in chronic pancreatitis / J. Kellerund, P. Layer // Pancreapedia. - 2015. - Vol. 2015. - P. 1-7. DOI: 10.3998/ panc.2015.37.

5. Goulden M. R. The pain of chronic pancreatitis: a persistent clinical challenge / M. R. Goulden // Br. J. Pain. - 2013. - Vol. 7 (1). - P. 8-22. DOI: $10.1177 / 2049463713479230$.

6. Warshaw A.L. AGA Technical review: treatment of pain in chronic pancreatitis / A. L. Warshaw, P. A. Banks, C. Fernández-Del Castillo // Gastroenterology. - 1998. - Vol. 115 (3). - P. 765-776. DOI: 10.1016/s00165085(98)70157-x.

7. Ewald N. Diagnosis and treatment of diabetes mellitus in chronic pancreatitis / N. Ewald, P. D. Hardt // World J. Gastroenterol. - 2013. - Vol. 19 (42). - P. 7276-7281. DOI: $10.3748 / w j g . v 19 . i 42.7276$.

8. Forsmark C. E. Management of chronic pancreatitis / C. E. Forsmark // Gastroenterology. - 2013. - Vol. 144 (6). P. 1282-1291. DOI: 10.1053/j.gastro.2013.02.008.

9. Evidence-based clinical practice guidelines for chronic pancreatitis 2015 / T. Ito, H. Ishiguro, H. Ohara [et

\section{REFERENCES}

1. Melamed P, Melamed F. Chronic metabolic acidosis destroys pancreas. Biotherapy Clinic of San Francisco, USA. JOP. 2014;15(6): 552-60. Available from: https://doi. org/10.6092/1590-8577/2854.

2. Cruz-Monserrate Z, Gumpper K, Pita V, Hart PA, Forsmark C, Whitcomb DC, et al. Biomarkers of chronic pancreatitis: a systematic literature review. Pancreatology. 2021;21(2): 323-33. Available from: https://doi.org/10.1016/j. pan.2021.01.006.

3. Lomakina EY, Taratina OV, Belousova EA. Chronic pancreatitis and diabetes mellitus: a review of the literature. Almanac Clin Med. 2019;47(6): 525-34. Available from: https://doi.org/10.18786/2072-0505-2019-47-075.

4. Kellerund J, Layer P. Diagnosis of pancreatic exocrine insufficiency in chronic pancreatitis. Pancreapedia. 2015;2015: 1-7. Available from: https://doi.org/10.3998/ panc.2015.37.

5. Goulden MR. The pain of chronic pancreatitis: a persistent clinical challenge. $\mathrm{Br} J$ Pain. 2013;7(1): 8-22. Available from: https://doi.org/10.1177/2049463713479230.

6. WarshawAL, Banks PA, Fernández-Del Castillo C. AGA Technical review: treatment of pain in chronic pancreatitis. Gastroenterology. 1998;115(3): 765-76. Available from: https://doi.org/10.1016/s0016-5085(98)70157-x. al.] // J. Gastroenterol. - 2016. - Vol. 51 (2). - P. 85-92. DOI: 10.1007/s00535-015-1149-x.

10. Chronic pancreatitis leading to pancreatogenic diabetes presenting in diabetic ketoacidosis: a rare entity / G. Melkia, L. Lahama, G. Karima [et al.] // Gastroenterol. Res. - 2019. - Vol. 12 (4). - P. 208-210. DOI: $10.14740 / g r 1203$.

11. Petrov M. S. Post-pancreatitis diabetes mellitus: prime time for secondary disease / M. S. Petrov // Eur. J. Endocrinol. - 2021. - Vol. 184 (4). - P. R137-R149. DOI: 10.1530/EJE-20-0468.

12. Steinberg J. Type 2 Diabetes Therapies: A STEPS Approach / J. Steinberg, L. Carlson // Am. Fam. Physician. - 2019. - Vol. 99 (4). - P. 237-243. - Access mode : https:// www.aafp.org/afp/2019/0215/p237.html\#: :text=Type\%20 2\%20Diabetes\%20Therapies\%3A\%20A\%20STEPS\%20 Approach\%20,Exenatide\%20weekly\%3A\%20...\%20\%20 4\%20more\%20rows\%20.

13. Lactate, a neglected factor for diabetes and cancer interaction / Y. Wu, Y. Dong, M. Atefi [et al.] // Mediators Inflamm. - 2016. - Vol. 2016. - 6456018. DOI: $10.1155 / 2016 / 6456018$.

14. Про затвердження та впровадження медикотехнологічних документів зі стандартизації медичної допомоги при хронічному панкреатиті: адаптована клінічна настанова 2014. 2 // Наказ Міністерства охорони здоров'я України від 10.09.2014 № 6384. - Режим доступу: http://uoz-chernigov.at.ua/publ/normativna_baza/ medicina/nakaz_moz_ukrajini_vid_10_09_2014_638/7-1$0-600$

15. Галушко О. А. Інтоксикаційний синдром в практиці внутрішніх хвороб: роль і місце Реосорбілакту / О. А. Галушко, С. М. Недашківський // Газета «Новини медицини і фрармації». - 2020. - № 3 (715). - Access mode: www.mif-ua.com/archive/article/49014.

7. Ewald N, Hardt PD. Diagnosis and treatment of diabetes mellitus in chronic pancreatitis. World $\mathrm{J}$ Gastroenterol. 2013;19(42): 7276-81. Available from: https://doi.org/10.3748/wjg.v19.i42.7276.

8. Forsmark CE. Management of chronic pancreatitis. Gastroenterology. 2013;144(6): 1282-91. Available from: https://doi.org/10.1053/j.gastro.2013.02.008.

9. Ito $\mathrm{T}$, Ishiguro $\mathrm{H}$, Ohara $\mathrm{H}$, Kamisawa T, Sakagami J, Sata N, et al. Evidence-based clinical practice guidelines for chronic pancreatitis 2015. J Gastroenterol. 2016;51(2): 85-92. Available from: https://doi.org/10.1007/s00535-0151149-x.

10. MelkiG, LahamL, KarimG, KomalF, KumarV,BarhamS, et al. Chronic pancreatitis leading to pancreatogenic diabetes presenting in diabetic ketoacidosis: a rare entity. Gastroenterol Res. 2019;12(4): 208-10. Available from: https://doi.org/10.14740/gr1203.

11. Petrov MS. Post-pancreatitis diabetes mellitus: prime time for secondary disease. Eur J Endocrinol. 2021;184(4): R137-49. Available from: https://doi.org/10.1530/EJE-200468.

12. Steinberg J, Carlson L. Type 2 diabetes therapies: A STEPS approach. Am Fam Physician. 2019;99(4): 23743. Available from: https:// www.aafp.org/afp/2019/0215/
$4(10), 2021$ 
p237.html\#: : text=Type\%202\%20Diabetes\%20 Therapies $\% 3$ A $\% 20$ A $\% 20$ STEPS $\% 20$ Approach $\% 20$ ,Exenatide\%20weekly\%3A\%20...\%20\%204\%20more\%20 rows $\% 20$

13. Wu Y, Dong Y, Atefi M, Liu Y, Elshimali Y, Vadgama JV. Lactate, a neglected factor for diabetes and cancer interaction. Mediators Inflamm. 2016;2016: 6456018. Available from: https://doi.org/10.1155/2016/6456018.

14. [On approval and implementation of medical and technological documents for standardization of medical care for chronic pancreatitis: adapted clinical guideline 2014. 2. Order of the Ministry of Health of Ukraine dated September 10, 2014 No. 6384]. Available from: http://uozchernigov.at.ua/publ/normativna_baza/medicina/nakaz moz_ukrajini_vid_10_09_2014_638/7-1-0-600. Ukrainian.

15. Halushko OA, Nedashkovsky SM. [Intoxication syndrome in the practice of internal diseases: the role and place of Reosorbilakt]. Hazeta «Novyny medytsyny i farmatsii». 2020;3(715). Available from: www.mif-ua.com/ archive/article/49014. Ukrainian. 